\title{
Environmental practices in the wine industry: an overview of the Italian market
}

\author{
Romeo Bandinelli \\ University of Florence, Italy \\ Diletta Acuti \\ University of Portsmouth, Portsmouth, UK, and \\ Virginia Fani, Bianca Bindi and Gaetano Aiello \\ University of Florence, Italy
}

Environmental practices in wine industry

Received 30 August 2019 Revised 5 November 2019 16 December 2019 10 January 2020

Accepted 20 January 2020

\begin{abstract}
Purpose - The present research expands the debate on environmental sustainability in the wine industry. Since the literature on sustainability and wine is relatively recent, current results do not cover all the practices that can be implemented along the wine supply chain. Thus, the paper presents a classification of environmental practices specific for the wine industry, according to the increased attention that has been paid to this topic in recent years. Moreover, it investigates the adoption level of these practices with reference to Italian wine producers. Design/methodology/approach - The research presents a systematic literature review including papers published in academic journals during the past 30 years and in Italian specialised magazines. This methodology is useful to provide a clear overview of sustainable practices that can be adopted along the wine supply chain. Therefore, an empirical study based on the results of an online survey shows how wineries approach environmental sustainability.

Findings - The literature review provides a definition and classification of environmental practices in the wine industry, as well as identification of those that require further attention in the literature, suggesting future research paths. The results of the online survey give an overview of the adoption level of environmental practices and highlight widespread attention to all the listed environmental practices, including those not adopted.

Originality/value - From a theoretical point of view, this paper fills a literature gap in terms of the definition and classification of environmental practices that cover all wine supply chain processes, also providing a useful instrument for wine companies' managers. Moreover, the results of the empirical research give an overview of the adoption level of environmental practices in one of the most relevant countries in terms of wine production and highlight widespread attention to all the listed environmental practices, including those not adopted.
\end{abstract}

Keywords Wine, Environment, Sustainability, Empirical study

Paper type Research paper

\section{Introduction}

In recent years, the global wine industry has becoming increasingly important, and today it constitutes one of the most significant industries in countries such as Italy (the biggest wine producer in the world), where it also stands as a symbol of outstanding quality. Before the 1970s, wine production and consumption were primarily concentrated in Europe. Subsequently, the market has been opened to other countries such as Australia, New Zealand, South Africa and South America. Most recently, the wine market has reached China, which follows the previous path of the US in developing a promising domestic market. At the same time, the geographic expansion has pushed the market towards wide diversification in terms of products and packages, with bulk wine and packages other than glass bottles

(C) Romeo Bandinelli, Diletta Acuti, Virginia Fani, Bianca Bindi and Gaetano Aiello. Published by Emerald Publishing Limited. This article is published under the Creative Commons Attribution (CC BY 4.0) licence. Anyone may reproduce, distribute, translate and create derivative works of this article (for both commercial and non-commercial purposes), subject to full attribution to the original publication and authors. The full terms of this licence may be seen at http://creativecommons.org/licences/by/4.0/legalcode

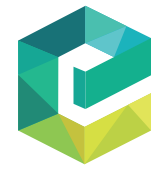

British Food Journal Vol. 122 No. 5, 2020 pp. $1625-1646$ Emerald Publishing Limited DOI 10.1108/BFJ-08-2019-0653 
$\mathrm{BFJ}$

122,5

1626

increasing their stake in the market. In fact, each country has developed its own stylistic identity, focussing on a specific consumer target.

In the next five years, global consumption is estimated to increase significantly, by 21.6 per cent in China, 5.1 per cent in Russia and 5.7 per cent in the US (Istituto di Servizi per il Mercato Agricolo Alimentare, 2017).

The growth of the wine industry highlights the importance of making this industry sustainable throughout the entire supply chain. The wine industry influences the physical environment where it operates; at the same time, its future viability is inextricably linked to environmental impacts and conditions (Christ and Burritt, 2013; Vrontis et al., 2016). Thus, as a key mediator between people and the planet, sustainable agriculture has considerable potential to address many sustainability challenges, strengthen livelihoods, revitalise rural and urban landscapes and deliver inclusive national growth (Mueller Loose and Remaud, 2013). Indeed, consumers recognise the efforts of wine companies which tend to be sustainable and respect the environment, for example, organic wines with an eco-label guarantee are perceived by consumers as healthier and environmentally friendly, and the "organic" attribute influences consumer preference and increases the perceived wine value (Bernabéu et al., 2008).

Because of the massive scale of wine production and distribution, and the associated environmental implications, it is crucial to analyse and optimise the wine supply chain considering its specific production stages (Varsei and Polyakovskiy, 2017). The wine supply chain encompasses all activities associated with the flow and transformation of the product from the raw materials stage through to the end user. Implementing a sustainable wine supply chain requires companies to deal with sustainability issues with reference to each stage of the production and distribution process. Consequently, it is critical for companies to be aware of the practices they can implement along the entire wine supply chain in order to respect the environment.

Although research on sustainability in the wine industry is rather recent, several studies recognise the relevance of this topic. For instance, a stream of the literature has focussed on specific stages of the wine supply chain, such as production (Point et al., 2012) or distribution (Fiore, 2006).

Other studies have focussed on the specific consequences of unsustainable practices of wine companies, such as gas emissions (Jradi et al., 2018) or water overconsumption (Taylor, 2006). However, literature still lacks a complete analysis of the entire wine supply chain and related consequences for the environment.

Hence, the need to provide managers with a clear overview of sustainable practices that can be adopted, organised within a clear framework. To this end, the research incorporates the whole wine company supply chain, from the viticulture phase to distribution. More specifically, environmental sustainability practices are linked to vineyard, winery and postwinery subsystems that include viticulture, vinification and winery and bottling and distribution, respectively. The lifecycle assessment (LCA) methodology helps to classify each practice according to its impact on air, water, plants and soil and landscape and society.

Therefore, the research seeks to evaluate the adoption of specific sustainable practices within the wine industry and their degree of implementation in the Italian context. This is highly pertinent because Italy has been the world's leading wine producer for several years.

The present work is structured as follows: in the first section, the paper examines the sustainability concept with specific attention to its application in the wine industry. The second section presents the research questions and methodology. The third section summarises the main findings. Finally, the last section provides conclusions and offers suggestions for the development of further research.

\subsection{Sustainability in today's world}

The term "sustainability" has its etymological origins in the Latin verb sustinere, with the twofold meaning of holding on and making sure that a certain thing lasts, as well as taking 
charge and taking on a commitment (Silvestri, 2015). These two complementary aspects can be summed up as the preservation of something that exists in the present (i.e. nature) and that must be maintained in the future and as the assumption of responsibility by someone (i.e. humanity) (Schwartz and Carroll, 2003). Sustainability in today's world requires that businesses should focus not only just on the limitation of their impact on the society but also on the advancement of the social, economic and environmental conditions of the contexts in which they operate (Del Giudice et al., 2017).

This concept reflects the three dimensions of sustainability currently adopted: economic, social and environmental sustainability (Elkington, 1994). Consequently, talking about "sustainability" means talking about a sustainable scenario that includes all three dimensions: they are complementary and have the same level of importance and ignoring one implies having only a partial perspective of sustainability (Borra et al., 2016). It is generating long-term profits, while consuming environmental resources efficiently and effectively reducing environmental pollution and adding value to the community within which they operate (Cooper, 2017; Fiandrino et al., 2019).

More specifically, environmental sustainability, which represents the starting point of the worldwide debate regarding the sustainability concept, refers to the ecosystem and evaluates the balance between local population consumption and resource abundance (i.e. natural capital) within a geographical area (Acuti and Bellucci, 2019). Environmental aspects are related to the implementation of practices which, through the efficient use of resources (Keijzers, 2002), the reduction and continuous monitoring of pollutant emissions and the evaluation of the environmental impact caused by longer product lifecycles (Meier et al., 2015), limit the impact on natural resources for future generations.

On the other hand, economic sustainability evaluates economic growth pertaining to monetary, human and natural capital through the rational and efficient use of resources, ensuring that benefits exceed costs. The economic dimension refers to the connection between the success of the organisation and the value it can add to the economic system where it operates, for both present and future generations (Schwartz and Carroll, 2008). In this context, emphasis should be placed on knowledge sharing within companies, process management and reporting activities related to sustainability (Bellucci et al., 2019).

Finally, social sustainability refers to providing the same access to resources to the entire population, both today and in the future. Thus, the social dimension refers to equal practices in terms of labour, human capital and behaviour towards the community, considering value creation for the whole society as the ultimate objective (Alhaddi, 2015).

In parallel with the institutional perspective, sustainability has widely declined in terms of both behaviours and activities at the single company level, introducing the concept of corporate sustainability. Accordingly, the perspective moves from the macro-to microdimension of sustainability, whereby the relevant sustainability assets (i.e. economic, environmental and social) affect the business strategies implemented by a specific company (Figge et al., 2002). Corporate sustainability is a constantly evolving field and represents a business strategy to gain competitive advantage through the implementation of production processes focussed on environmental preservation and social equity (Franceschelli et al., 2018; Wilson, 2003), as well as adopting innovative sustainable practices for human resource management (Dunphy et al., 2003).

In order to address the high competition within the agri-food industry, sustainability and innovation practices can be strategically effective, especially with an open sustainability innovation approach. Indeed, increased attention towards environmental issues offers a more credible and valid company image for customers and business partners (Arcese et al., 2015; Del Giudice, 2019). Hence, having a culture of proactive environmental responsibility is not only a source of competitive advantage for many firms but also a source of value for their stakeholders (Scuotto et al., 2019) . 
$\mathrm{BFJ}$

122,5

1628

The implementation of sustainable practices is often hindered by the short-term vision of managers who are more focussed on the required costs than on the potential competitive advantage that can be gained (Chouinard et al., 2011). Thus, environmental regulations promote innovation within companies, creating new business opportunities that are oriented towards cost savings and greater process efficiency (Pullman et al., 2010; Yuan and Xiang, 2018). Especially over the last decade, the increasing pressure from governments and society has led companies within the agri-food industry to align business practices with environmental sustainability principles. Accordingly, sustainable business models have been used as targeted approaches to incorporate sustainability practices into decision-making and to reduce negative impacts on both the environment and society (Caldera, 2017).

\subsection{Environmental wine practices: introduction to the state of the art}

Although sustainability has been examined in the case of the food industry (Barth et al., 2017; Civera et al., 2019), some market segments, such as wine, need further research (Marshall et al., 2005; Rueda et al., 2017). In fact, wine is perceived as an important beverage in the agricultural industry that is both affected by climate change and considerably affects the environment (Mozell and Thach, 2014). Therefore, the literature has started to analyse how the wine industry contributes to climate change by identifying tools for estimating its impact on global warming (Benedetto, 2013).

More generally, wine production has multiple impacts on the environment, primarily related to the use of fertilisers and plant protection products in vineyards (Serio et al., 2018), as well as bottling (Gabzdylova et al., 2009; Villanueva-Rey et al., 2014). Thus, wine production has to be carried out while preserving natural resources for future generations, identifying the traditional or innovative practices that allow the development of high-quality products with the lowest possible negative impact on the environment.

The relevance of studying sustainable wine production practices resides in the growth of the wine industry and in the desire for sustainable wine expressed by consumers (Mann et al., 2012), who increasingly consider environmental impacts during the purchase process (Wiedmann et al., 2014).

Despite the evidence that the wine industry has not received the same attention by politicians and the media reserved for others, such as the chemical industry, several issues should be considered by wine producers (Ene et al., 2013). Studies on the implementation of sustainability practices in the wine supply chain can be found from the early 1920s, mostly focussed on analysing producers' perspectives, especially in New Zealand, a country that has demonstrated a strong commitment to introducing sustainability within the production processes (Szolnoki, 2013).

In recent years, research interest in the application of sustainable strategies to the wine industry has grown, along with the development of several scientific committees focussed on related issues (Santini et al., 2013). This evidence reflects the increased attention paid to this topic, which can be included in mainstream studies related generally to sustainability in agriculture.

The 1960s saw the emergence of the so-called Green Revolution, a paradigm based on the significant utilisation of mechanisation systems and synthetic chemicals in order to achieve higher productivity at the lowest possible expense (Wojtkowski, 2006). Even if some benefits were gained, such as a reduction in mortality rates related to hunger, these strategies resulted in dangerous environmental impacts, causing erosion and soil degradation.

The strategies that represented the solution to the problems of the past have become the objects of investigation in the present: the actual challenge is the development of a business model ensuring profitability that moves from a conventional to a sustainable agriculture 
system (Jerram, 2015). Accordingly, increased attention has been paid to the role of institutions in promoting social and environmental practices in agriculture (Blewitt, 2008).

\section{Methodology}

In order to define the state of the art of the sustainability concept in the wine industry, a systematic literature review has been conducted. Even if a great number of works refer to the implementation of the sustainability concept by companies operating in the market analysed, sustainability practices have never been listed and classified along the entire wine supply chain. Therefore, the first research question can be summed up as follows:

$R Q 1$. What are the environmental practices that wine companies can implement and how can they be classified according to wine supply chain processes?

In order to answer this research question, the authors adopt a systematic literature review, since it is a convenient methodology to conduct a transparent and replicable study, following fixed inclusion and exclusion criteria (Johnsen et al., 2017; Yang et al., 2017).

The systematic literature review includes academic management articles that address sustainable practices in the wine industry (Voorberg et al., 2015). In order to include the potential broad list of studies that might address the sustainable practices that companies can implement within the wine industry, specific keywords were selected and searched on the AgEcon, Agricola, Business Source Premier (EBSCO), Science Direct and Springer databases as part of the paper's title, abstract or keywords. The term "wine" was combined with "CSR", "sustainability*", "lifecycle", "eco", "organic" or "environment*." Although our research is framed in the sustainability literature, other complementary constructs have been included as keywords. "Sustainability" has been selected because it emphasises the long-term nature of the benefit that business is expected to provide to society, and it shifts the company's perspective to the environment and future generations more explicitly than any of the other frameworks (Schwartz and Carroll, 2008). However, some confusion with complementary constructs has been found in literature-for example, in some papers, the terms "CSR" and "eco" are interchangeably used. Indeed, although corporate social responsibility (CSR) and sustainability have different peculiarities, both acknowledge that companies' need to reduce the negative effect of their production on the economy, environment and people and to balance their profit goals responsibly with the needs of the society (Hutchins and Sutherland, 2008). There are also strong linkages between the concepts of sustainability and CSR and the term "ecological," which refers to the impact of companies on the environment. For instance, the ecological footprint measures the natural capital demand of human activities and is widely used to demonstrate the (un)sustainability of companies' activity on individual, local and global scales (Niccolucci et al., 2008).

To overcome these incongruities and to include all the practices useful to managers to implement a sustainable wine supply chain, these terms were searched as part of a paper's title, abstract or keywords (Caldera et al., 2017).

Only English language records, published in academic journals, covering the past 30 years (i.e. papers from 1 January 1988 to 31 December 2018) were selected. The list was also integrated with specialised Italian magazines (both English and Italian written records), such as Agriregionieuropa, L'Informatore Agrario, Agricoltura, Vite Vino and Qualità and Il Corriere Vinicolo. Articles were manually selected by evaluating the title and abstract for relevance, and duplicates were eliminated. A total of 146 academic papers, 18 books and 134 sectorial specialised magazines were collected. The journals containing the most studies on sustainable wine practices include Journal of Cleaner Production (17), Wine Economics and Policy (6), British Food Journal (5) and Sustainability (5). In order to enrich the research, practical examples were then collected from companies' websites, report templates or
Environmental practices in wine industry 
$\mathrm{BFJ}$

122,5

1630

sustainability reports, which helped provide real case studies. In addition, workbooks addressed to operators within the sector were analysed, such as the Ozark Mountain Vineyard Sustainability Assessment Workbook and the third edition of the California Code of Sustainable Winegrowing.

Once the environmental practices were defined, an empirical evaluation of their implementation in a real context was undertaken in order to assess if and how they are utilised. To enhance the value of this analysis, the sampled companies were Italian, according to the fact that Italy represents the world's largest wine producer.

Thus, the second research question can be summarised as follows:

$R Q 2$. Which environmental practices within the defined framework are mostly adopted by Italian wine producers?

Starting from the results of the literature review, we conducted an online survey involving Italian wine producers.

In order to define the sample, we used a database of Italian companies available on the Internet, resulting in a list of 5,700 Italian wine producers. Within the sample, only 9 per cent employ more than 20 people and 21 per cent gross more than 500,000 euros. Moreover, only 40 per cent of companies produce more than 500,000 bottles per year.

Starting from these data, the sample was reduced to 513 companies, including only those with more than 20 employees. We collected 78 questionnaires, with a response rate of 15 per cent. All the Italian regions were represented, with a prevalence of the Tuscany region; 60 per cent of the companies' profit was constituted by Denominazione di Origine Protetta (DOP) wines, followed by indicazione geografica tipica (IGT), sparkling or semi-sparkling wines. The selling price of more than half of the bottles produced by 40 per cent of the companies was between 5 and 50 euros, while 37 per cent were sold for between 10 and 20 euros.

We structured the questionnaire as reported in Table I. Respondents were asked to indicate whether they had already adopted each practice, if they planned to adopt it in the future or if they were not going to adopt it. Moreover, we asked for the level of importance they ascribed to each practice.

\section{Findings and analysis}

\subsection{Environmental practices framework}

Starting from the evidences highlighted through the review of academic and industry journals, this section reports the results related to RQ1 (i.e. what are the environmental practices that wine companies can implement and how can they be classified according to the supply chain processes?) A set of practices that wine companies can implement are listed and some examples of their implementation in real contexts are provided.

Table I summarises the 20 identified sustainable practices, classified according to two dimensions.

The first dimension regards the process involved within the wine supply chain, from the viticulture phase to distribution. More specifically, according to the macro classification of Point et al. (2012), environmental sustainability practices are linked to vineyard, winery and post-winery subsystems that include viticulture, vinification and winery and bottling and distribution, respectively.

The second dimension shows the primary beneficiaries related to the adoption of environmental practices and deals with the LCA methodology, where each practice has been classified according to its impact on air, water, plants and soil and landscape and society. This analytical approach represents a key reference for the international scientific community involved in the assessment of sustainability (Benedetto, 2013; Zamagni, 2012). 


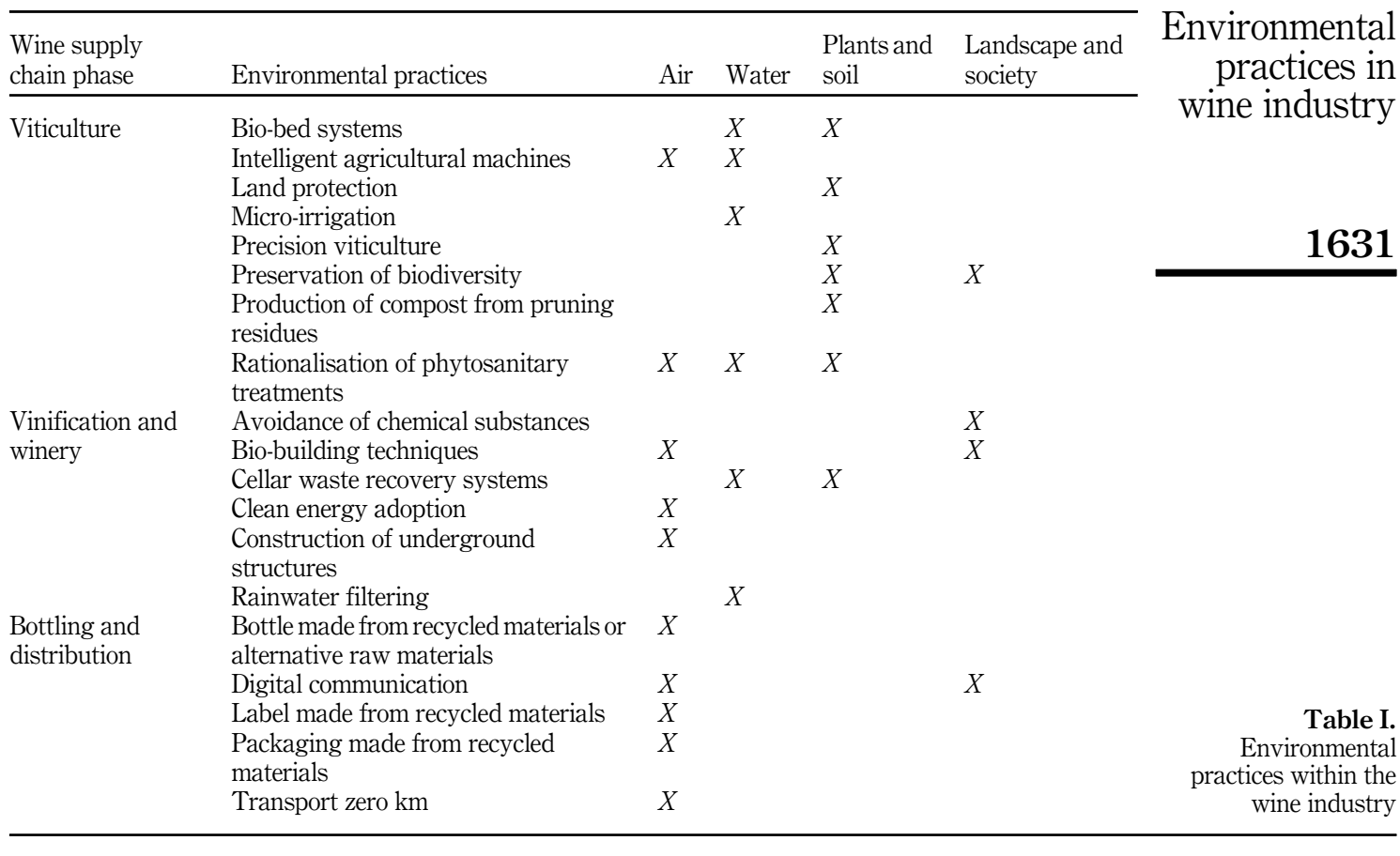

It is important to highlight that we collected only those environmental practices related to the wine industry: general or mandatory practices are not included, although they are discussed throughout the paper.

The wine industry is flexible in addressing many important emerging environmental issues such as water use, air quality and energy use (Ohmart, 2004). As highlighted by Borsellino et al. (2016) and the Organisation for Economic Co-operation and Development (OECD, 2002), such flexibility enables producers to choose amongst different sustainability paths and several sustainable business models. Together, the specificities of local culture, society and the economy can generate a variety of methods to implement sustainability at a local level (Zanoli, 2007).

In the following sections, we show some examples of environmental practices that wine producers can adopt, grouped by the related supply chain process showed in Table I. The complete list of practices and related descriptions can be found in the Table AI.

3.1.1 Viticulture. Viticulture is naturally linked to the environment, vineyards being an integral part of the surrounding territory. Therefore, careful management of the vineyard represents not only the starting point for obtaining a sustainable product but also a necessary condition to defend and enhance the landscape and territorial identity (Miglietta et al., 2015; Miglietta and Morrone, 2018a).

Producers can preserve the landscape by adopting several practices. The protection of agricultural lands as environmental resources is one of the objectives recommended by the European Union (EU), together with the safeguarding of water and air resources (Bonamente et al., 2015). Looking towards soil protection, producers can reuse the stones extracted from the ground during the making of vineyards, building walls and terraces to prevent potential landslides. Producers can also improve the grass growth, sowing herbs in the area between the vineyard rows at the end of the summer season following harvesting. Plant roots go very 
$\mathrm{BFJ}$

122,5

1632

deep into the soil, guaranteeing basic ingredients for high-quality wine. At the same time, excessive use of chemical fertilisers, avoided by implementing sustainable techniques, will result in their absorption, significantly damaging the soil in the long term. In addition to providing necessary nourishment to the soil, improving the grass growth has the advantage of reducing the potential problems of hydrogeological instability caused by the vertical arrangement of vineyards, limiting water accumulation for the final vines and leading to uneven ripening (Badii, 2015). It also helps to bring microelements such as iron, boron, chlorine and manganese to the surface and to increase biodiversity. In order to achieve optimal growth in the vineyard, attention has to be paid to the site selection and the vineyard characteristics in terms of chemical-physical analysis (Mcmanus, 2008). This reduces the possibility of negative economic impacts and enables producers to obtain high-quality wines. Moreover, the more attention paid to the selection of suitable land, the fewer interventions are necessary, resulting in cost saving and higher wine prices.

Environmental protection also comprises the preservation of biodiversity, the living species and biological variety present in a particular habitat (Duru et al., 2015). Maintaining a high level of biodiversity is essential because conservation of the natural environment is facilitated by the capacity of living organisms to evolve and adapt them to change. The vineyard is tied to the ground because the "brain" of the plant resides in the roots. Achieving a good soil condition is fundamental to creating a suitable environment to ensure root activity, the balanced and healthy development of the vines and high-quality grape (Pretorius et al., 1999). The success achieved by mechanised agriculture in recent decades has to be reviewed due to the substantial deterioration of organic substances. The contribution of organic carbon is obtainable through sustainable management of the land based on grassing and reduced processing, which limits the risk of desertification through a high-quality physical-chemical composition. Over time, it also contributes to achieve microbiological biodiversity and soil macroporosity, allowing a greater water reserve.

The selection of rootstocks can therefore facilitate an effective response to climate change, which may otherwise negatively affect companies' profitability. Indeed, the selection of rootstocks with high resistance to the crop conditions that cause adverse effects (such as water scarcity or salinity) enables an adaptive response not only under controlled growth conditions but also in full fields with various pedoclimatic environments and grafting combinations (Romero et al., 2018).

Attention must also be addressed to biodiversity, including all the landscape elements, for example, the presence of birds is used as an evaluation parameter to measure ecosystem health, as well as being beneficial because these species feed on insects that are harmful to the vine. In order to ensure their presence, as well as that of other animals such as rodents or slugs, it is important to maintain traditional elements within the vineyard (Assandri et al., 2017). Another concrete example of attention to biodiversity preservation is represented by one of the Italian companies analysed, which effectively divides its territory between forest and cultivated areas: the company has planted numerous kilometres of cypress trees, 10 hectares of cork oaks and new woods across a total of 1,000 hectares. Across the seasons, the vegetation includes 120 spontaneous herbaceous species, none of which is aggressive towards the vines. This variety also guarantees rich and diverse natural fauna, moderated by management plans according to regional regulations.

In order to reduce environmental pollution, it is also possible to rationalise phytosanitary treatments. According to the recommendations of The International Organisation of Vine and Wine Resolution 1/2008 for sustainable viticulture, it is necessary to dose fertilising and agrochemical treatments carefully, with the aim of reducing quantities via targeted and optimal distribution, paying attention to weather conditions (OIV, 2008). Indeed, numerous treatments diminish the microbiological heritage of the vineyard and increase the risk of developing resistance to crop protection products. The use of signalling plants as biological 
detectors of certain diseases can help in identifying diseases and prevent the use of chemical treatments.

Moreover, filling, cleaning and rinsing operations of agricultural sprayer machines can lead to leaks and spills of plant protection products and oily residues. These sources of pollution represent a major cause of water pollution due to the use of crop protection products (Miglietta et al., 2018).

In order to prevent the dispersion of residues in the environment, it is possible to use biobed systems in specific areas where waters are conveyed. The soil layers in these areas consist of a particular organic mix composed of straw, peat and soil, able to degrade the polluting molecules through the action of microorganisms. Such a composition can be effectively replaced by other mixes containing olive leaves, grape stalks and other lignocellulosic materials that are readily available in Southern Europe (Karanasios, 2010).

In order to reduce water waste, producers can use micro-irrigation. This includes a system of dispensers connected to each other by low-pressure synthetic polymer pipes and placed near the plant at its roots to release drip irrigation. It is often used during periods of high water stress, allowing efficient water use by small volume and uniform distribution. Compared to irrigation by sliding, based on the slope of surfaces, micro-irrigation allows only a specific soil surface to be wet, avoiding excessive evaporation and extended soil erosion (Raimondi, 2014). Unlike rain irrigation, micro- irrigation does not wet leaves, preventing the development of parasitic fungi. Furthermore, it can be combined with fertigation mechanisms, allowing an appropriate and limited dosage of fertilisers. The sustainability of this practice is confirmed by Technical Brief no. 15 of the Sustainable Agriculture Initiative; this study has decreed drip irrigation as the most efficient solution to improve water productivity (SAI, 2015).

Of course, technology supports producers in improving the sustainability of their activities, for example, precision viticulture is a new management technology aimed at optimising inputs in order to increase crop yield, quality and profits. Precision viticulture is about collecting data on crop performance by providing a high-quality spatial resolution. Viticulture requires precision in its development due to the high level of variability that characterises each vineyard (Profitt and Bramley, 2006). In order to simplify vineyard management, the increased mechanisation has resulted in a generic homogenisation and standardisation of vineyard treatments at the expense of solving specific needs, with negative impacts in productive and environmental terms. However, a recent countertrend has led to greater interest in the implementation of practices specific to the site conditions, aimed at a more sustainable form of viticulture. Thanks to innovations introduced in the field of information technology and geographic sciences, many ways to develop customised solutions to support precision in agriculture are available today, facilitating high-quality production while reducing environmental impacts. The diffusion of open source data management solutions, which are currently growing as a need to support vineyard management (De Filippis et al., 2010), has enhanced the development of portals based on geographic information systems, enabling a large audience to access geographical data.

These new technological tools facilitate the reduction of energy consumption and the optimisation of specific phases of the wine-making process, for example, all the measurements obtained through wireless and Global Positioning System sensors can be transmitted to advanced agricultural machines in order to diversify the treatments in accordance with the specific needs of each plant, avoiding the application of an undifferentiated approach (Stasi et al., 2016). In fact, the proximity sensors installed on such machines allow automatic adjustment of the dosage, speed and rotation angle of treatment operations without human intervention.

3.1.2 Vinification and winery. Most of the previously explained actions facilitate the adoption of sustainable practices in vinification and winery. In fact, they allow the removal or, 
$\mathrm{BFJ}$

122,5

1634

at least, a substantial reduction of many chemical interventions used in the conventional treatment of grapes and the management of winemaking. Under the impetus of greater environmental sensitivity to the impacts of agricultural processes, even cellars can be rethought in order to minimise waste and emissions and to become totally self-sufficient regarding energy. Sustainable winery aims to transform the production of wine into a cyclical production process, where the energy required by machinery and buildings comes directly from the waste of agricultural activities, as well as the natural resources of the surrounding environment.

Due to particular materials and construction techniques, it is possible to maintain a constant temperature inside cellars over the year, achieving satisfactory environmental performance. It is essential to find a balance between design and technology that enables the construction to be perfectly harmonised and integrated with the surrounding area and, at the same time, to ensure the functionality of each element in terms of responsible exploitation of resources (Briamonte, 2013).

The efficient construction of structures also enables producers to reduce their solar and convective thermal contributions, to control humidity values and to become totally integrated with the landscape. Producers can build hypogeal or partially buried structures, paying attention to the orientation in respect of the sun and the incidence of wind (Boulton, 2017). In this sense, the underground cellar of one of the analysed companies represents an excellent example; the Etruscan method of cyclopean boulders is used as natural mortars, perfectly integrated with the hilly landscape. Moreover, during the design phase of the whole structure, it is possible to reduce the distance between the vines, the winery and the storage of bottled wine in order to reduce carbon dioxide $\left(\mathrm{CO}_{2}\right)$ emissions. The use of a solar light collection system, consisting of ducted mirrors that convey sunlight into the rooms, allows advantage to be taken of natural lighting without resorting to electricity consumption, additionally obtaining economic benefits. Producers can also use vertical gardens to partially protect the cellar surface from the sun's rays, reduce the heat inside the workplace and thermally insulate the cellar walls. Moreover, producers can install solar panels on existing structures (for example, on the roof) or in uncultivated areas of the vineyard, ensuring that the supplied electricity derives entirely from renewable sources.

During the vinification process, certain practices can help in reducing the use of chemical substances, for example, sulphur dioxide $\left(\mathrm{SO}_{2}\right)$ is a colourless gas used as an additive in the wine industry despite its acknowledged toxicity, as highlighted by the World Health Organisation, which recommends a maximum daily dose of $0.7 \mathrm{mg} / \mathrm{kg}$ of body weight. Given the effects on human health and the growing pressure from consumers, the EU issued Directive 2003/89/EC and R, e.g. CE 1991/04, establishing that labels must report quantities of sulphites in wines above $10 \mathrm{mg} / \mathrm{L}$ (Thomas and Pickering, 2003). $\mathrm{SO}_{2}$ is used in oenology from the first stages of processing until bottling. It has a preservative and antioxidant action, protecting the wine from contact with oxygen during decanting and preventing the development of an oxidised smell and taste. It also enables antiseptic protection against mould, acetic bacteria and apiculate yeasts, guaranteeing the health, stability and quality of the wine. Despite the benefits of $\mathrm{SO}_{2}$, it is advisable to limit its use in order to avoid the already mentioned negative impacts on consumers' health. However, it cannot be totally eliminated, obtaining a wine without sulphites, because they are naturally produced by some yeasts present in the wine must.

The ozone treatments of grapes represents an alternative to the use of $\mathrm{SO}_{2}$, due to ozone's proprieties as an antiseptic and an enhancer of polyphenolic compounds, useful from an oenological perspective and not harmful to human health. Moreover, by rapidly turning into oxygen, the use of ozone does not present any risk to the environment. After manual harvesting and subsequent refrigeration, grapes are subjected to a saturated ozone atmosphere through a generator with a consumption of less than $1 \mathrm{kWh}$ (Bellincontro, 2017). 
Ozone can also be used to wash winemaking and glass sterilisation plants, replacing chemical products (e.g. chlorine) and enabling significant water saving, thanks to the filtration and reuse of ozonated water (Mencarelli and De Propris, 2014).

Moreover, during the winemaking process, producers can choose between the use of selected or indigenous yeasts, responsible for the transformation of sugar into alcohol (i.e. alcoholic fermentation). Selected yeasts are produced in the laboratory and guarantee fermentation without an unexpected event, but are often accused of creating standardised flavours (Zambonelli, 2004). In other words, selected yeasts generate uniform wines without any character of the soil where the grapes were grown and, in addition, negatively affect the biodiversity of indigenous yeasts (Pretorius, 2000). On the other hand, indigenous yeasts, which naturally sit on grape skins and in the surrounding air, guarantee a wine with a personality strictly linked to the territorial connotation of origin, although they require greater attention due to their acidity or unpleasant odour.

Wine producers can also decide to meet vegan needs and exclude animal-derived substances from their wine production, for example, they can perform wine fining treatments avoiding the use of animal proteins (e.g. casein, gelatin, egg and fish proteins), choosing alternative solutions that include the use of fining proteins extracted from plants, such as proteins from cereals, grape seeds, potatoes or legumes (Marangon et al., 2019).

3.1.3 Bottling and distribution. According to a study conducted by the University of Siena involved in the Salcheto Carbon Free project (2015), $\mathrm{CO}_{2}$ emissions that are strictly linked to packaging (38 per cent) and commercial sales activities (26 per cent). For this reason, it is important to summarise the practices that producers can adopt in order to reduce their impact on the environment during the post-winery processing phase (Navarro et al., 2017).

First of all, it is possible to use recycled materials for bottles, labels and packaging. Moreover, innovative methods of construction enable the realisation of sufficiently strong glass with less thickness. This practice requires a smaller amount of raw materials in production and reduces $\mathrm{CO}_{2}$ emissions and transport costs, as even a small reduction can increase the number of bottles that can be transported in a single pallet (Hartley, 2008). Companies can become greener by using alternative glass or packaging materials, such as polyethylene terephthalate (PET), Tetra Pak or bag-in-box. In fact, a 2006 study demonstrated that the impact in terms of $\mathrm{CO}_{2}$ emissions of some types of packaging can be under 50 per cent compared to the classic $750 \mathrm{ml}$ glass bottle (González-García et al., 2011). However, these solutions may engender two problems. The first problem relates to wine conservation, as none of these solutions can guarantee the same protection as glass to the entry of oxygen into the bottle, which causes oxidation (Thompson, 2010); the second problem concerns the acceptance of these solutions by consumers who are not inclined towards environmental issues (Barber, 2010) or who perceive a lower wine quality due to its packaging.

Regarding the purchase of cardboard packaging, priority should be given to suppliers who produce a high per cent of Forest Stewardship Council (FSC) certified recycled material. The recycling of one ton of paper results in a saving of $210 \mathrm{~kg}$ of $\mathrm{CO}_{2}$ during production and a reduction in emissions equal to $1,098 \mathrm{~kg} \mathrm{CO}$ eq/t of paper due to the lack of disposal (COMIECO, 2013).

The environmental impact can also be reduced through the use of FSC-certified corks and subsequent recycling. The widespread use of cork as the closing material of the wine bottle derives from the fact that it allows the taste of the contents to be protected while maintaining osmotic contact with the air. Following the experience of a pilot project launched by AGRIS Sardinia in 2005 with the collaboration of the World Wide Fund for Nature and FSC Italia, the first FSC37-certified forest stoppers were placed on the market. Due to its characteristics of totally recyclable material and thermal and sound insulation qualities, the cork cap's lifecycle continues with possible applications in bio-building, obtaining insulation materials that can be applied to walls.
Environmental practices in wine industry

1635 
$\mathrm{BFJ}$ 122,5

\section{6}

\section{Table II.}

Results of the online survey regarding sustainable practices within the wine industry
According to Colman and Päster (2007), the greatest environmental impact related to transportation pertains to the distribution of finished products to final consumers. The choice of transportation mode is also influenced by the markets served by the company: a zero $\mathrm{km}$ distribution, which is perfectly aligned to sustainability choices, would be inadequate to seize market opportunities deriving from sales in the large-scale retail trade or from foreign markets. Therefore, it is necessary to keep in mind the considerable differences in terms of grams of $\mathrm{CO}_{2} / \mathrm{t}$ per $\mathrm{km}$ that exist in the range of solutions between transport by sea (about $50 \mathrm{~g}$ of $\mathrm{CO}_{2} / \mathrm{t}$ per $\mathrm{km}$ ) and by air (over $500 \mathrm{~g}$ of $\mathrm{CO}_{2} / \mathrm{t}$ per $\mathrm{km}$ ). On the other hand, as suggested by Miglietta and Morrone (2018b), the role of trade in relaxing the impact of territorial resources has to be taken into account - for example, estimating the virtual water flows and economic water productivity related to the wine trade in order to evaluate water loss/savings achieved through bilateral trade relations.

\subsection{Adoption and importance levels of environmental practices in the Italian wine industry}

Starting from the framework proposed above, in Table II we report the results for RQ2 (i.e. which environmental practices within the defined framework are mostly adopted by Italian wine producers?) The results of the online survey are summarised as per cents.

In the survey, we explored the adoption level and the importance of the identified environmental practices, shown in the "Adoption level" and "Importance level" columns in Table II.

\begin{tabular}{|c|c|c|c|c|c|}
\hline \multirow[b]{2}{*}{$\begin{array}{l}\text { Wine supply } \\
\text { chain phase }\end{array}$} & \multirow[b]{2}{*}{ Environmental practices } & \multicolumn{3}{|c|}{ Adoption level } & \multirow{2}{*}{$\begin{array}{c}\text { Importance } \\
\text { level } \\
\text { Average }\end{array}$} \\
\hline & & Yes & No & $\begin{array}{l}\text { We are going } \\
\text { to adopt it }\end{array}$ & \\
\hline \multirow[t]{8}{*}{ Viticulture } & Bio-bed systems & $20.21 \%$ & $62.38 \%$ & $17.41 \%$ & 3.73 \\
\hline & Intelligent agricultural machines & $56.41 \%$ & $34.62 \%$ & $8.97 \%$ & 3.45 \\
\hline & Land protection & $47.43 \%$ & $48.72 \%$ & $3.85 \%$ & 3.37 \\
\hline & Micro-irrigation & $57.69 \%$ & $32.05 \%$ & $10.26 \%$ & 4.09 \\
\hline & Precision viticulture & $35.90 \%$ & $55.13 \%$ & $8.97 \%$ & 3.79 \\
\hline & Preservation of biodiversity & $65.38 \%$ & $29.49 \%$ & $5.13 \%$ & 4.10 \\
\hline & $\begin{array}{l}\text { Production of compost from } \\
\text { pruning residues }\end{array}$ & $35.90 \%$ & $52.56 \%$ & $11.54 \%$ & 3.51 \\
\hline & $\begin{array}{l}\text { Rationalisation of phytosanitary } \\
\text { treatments }\end{array}$ & $92.31 \%$ & $6.41 \%$ & $1.28 \%$ & 4.54 \\
\hline \multirow{6}{*}{$\begin{array}{l}\text { Vinification and } \\
\text { winery }\end{array}$} & Avoidance of chemical substances & $78.20 \%$ & $16.67 \%$ & $5.13 \%$ & 3.82 \\
\hline & Bio-building techniques & $10.25 \%$ & $78.21 \%$ & $11.54 \%$ & 3.47 \\
\hline & Cellar waste recovery systems & $38.47 \%$ & $46.15 \%$ & $15.38 \%$ & 3.56 \\
\hline & Clean energy adoption & $38.47 \%$ & $46.15 \%$ & $15.38 \%$ & 4.21 \\
\hline & $\begin{array}{l}\text { Construction of underground } \\
\text { structures }\end{array}$ & $10.25 \%$ & $78.21 \%$ & $11.54 \%$ & 3.47 \\
\hline & Rainwater filtering & $20.52 \%$ & $65.38 \%$ & $14.10 \%$ & 3.73 \\
\hline \multirow[t]{5}{*}{$\begin{array}{l}\text { Bottling and } \\
\text { distribution }\end{array}$} & $\begin{array}{l}\text { Bottle made from recycled } \\
\text { materials and alternative raw } \\
\text { materials }\end{array}$ & $43.59 \%$ & $42.31 \%$ & $14.10 \%$ & 3.74 \\
\hline & Digital communication & $61.54 \%$ & $25.64 \%$ & $12.82 \%$ & 4.00 \\
\hline & $\begin{array}{l}\text { Label made from recycled } \\
\text { materials }\end{array}$ & $24.36 \%$ & $66.67 \%$ & $8.97 \%$ & 3.24 \\
\hline & $\begin{array}{l}\text { Packaging made from recycled } \\
\text { materials }\end{array}$ & $43.59 \%$ & $42.31 \%$ & $14.10 \%$ & 3.74 \\
\hline & Transport zero km & $29.49 \%$ & $61.54 \%$ & $8.97 \%$ & 3.56 \\
\hline
\end{tabular}




\section{Discussion}

Across the literature review and the survey, the present research investigates the implementation of sustainable practices along the wine supply chain. Specifically, the research explores the sustainable practices that companies can implement and whether they are actually adopted by organisations. Overall, our findings indicate that wine companies can foster sustainability in different stages of wine production; however, few wineries apply a completely environmentally sustainable approach to their supply chain.

According to our systematic literature review, since the beginning of the new millennium, many scholars have recognised the importance of observing how sustainability has started to influence wine production. Moreover, consumers have become increasingly concerned about the impacts of conventional agricultural production practices in the environment (Forbes et al., 2009). Thus, while the way food is produced can be changed by regulation, market forces are a major driver in the way food chains develop. Here, consumers have a crucial role, rewarding more sustainable food production by their choices and, similarly, punishing less sustainable alternatives (Grunert, 2011). In line with this trend, companies are looking to make their production more sustainable, mostly in relation to the environmental perspective. The systematic literature review has confirmed how recent years have seen a burgeoning effort to explore environmental management within wine companies, but this body of research remains underdeveloped (Christ and Burritt, 2013), missing a complete overview of the entire wine supply chain. The reviewed literature evidences how wine companies can intervene in many stages of wine production. Moreover, since the wine industry is flexible in addressing many environmental issues, such flexibility enables producers to choose between different sustainability paths and several sustainable business models. The review also shows how good practices can positively affect not only the environment but also companies' profitability. This fact should encourage companies to implement sustainable practices along the wine supply chain.

The online survey shows the environmental practices that Italian companies mostly implement and which of these practices companies are willing to adopt. The adoption level varies a lot depending on the practice, ranging from a minimum of 10.25 per cent (bio-building techniques and construction of underground structures) to a maximum of 92.31 per cent (rationalisation of phytosanitary treatments). This dissimilarity can be explained by the costs related to the implementation of the sustainable practice. Since wine companies, especially in Italy, are small or medium enterprises, they do not have the resources to invest in the most sophisticated practices or in sustainable activities with a long-term return on investments. The different level of adoption is also affected by the impact of the practice on companies' profitability and the difficulty of implementing the practice in terms of expertise.

Analysing in depth the results shown in Table II, there is the evidence of the high importance of the environmental practices related to the viticulture phase. More specifically, reduction of the use of phytosanitary products represents the most adopted and most relevant sustainable practice, and shows the highest average value in terms of perceived importance. Similar evidences can be highlighted in terms of the practice related to the defence of biodiversity, showing how the producers mainly associate the sustainability concept with these themes. In addition, high importance is given to carbon footprint and water saving.

Moving to other practices related to vinification and winery and bottling and distribution, collected scores are lesser-used compared to the others, especially considering those practices related to the use of bio-building techniques and the construction of underground structures, that are least frequently adopted by Italian wine companies. This result can be explained by the high cost of investment in implementing such practices and, consequently, the long-term return on the investment. It is important to note that the Italian wine industry is mostly composed by micro or small companies, where building-type activities are usually evaluated
Environmental practices in wine industry

1637 
$\mathrm{BFJ}$

122,5

as extraordinary and are done only when they become necessary from a structural point of view.

\section{Conclusion and further research}

The motivation for the present research resides in expanding the debate on environmental sustainability in the wine industry. Since the literature on sustainability and wine is relatively recent, current results do not cover all the practices that can be implemented along the wine supply chain.

Our paper contributes to the literature on sustainability in several ways.

First of all, the literature review identifies environmental practices along the wine supply chain process. This overview of the interaction between sustainability and the entire wine supply chain is critical. By optimising along the entire sequence of steps involved in the production of wine, the greatest value can be produced at the lowest possible cost and sustainability can effectively be achieved (Linton et al., 2007). Thus, addressing environmental sustainability requires consideration of environmental impacts throughout the entire production process of wine. To ensure that more environmentally responsible decisions are made, decision-makers require tools that facilitate a more complete understanding of implementable practices and their potential impacts.

Secondly, all sustainable practices have been classified according to an LCA logic. The identification and classification of such practices is helpful to carry on the literature on sustainability, with specific reference to the wine industry. Indeed, this research is not limited to a broad definition of environmental sustainability within the analysed context, but specifies in depth which are the practices that contribute effectively and concretely to achieve sustainability.

Finally, the findings of the empirical research give an overview of the adoption level of environmental practices in one of the most relevant country in terms of wine production and highlight growing attention of companies to all the environmental practices listed, including those not adopted.

This research also presents clear practical implications related to the evidence that modern consumers expect companies to be socially responsible (Acuti et al., 2019). Accordingly, wine companies have significantly strengthened their commitment to more sustainable production. As sustainability becomes an ever more important part of wine companies' strategies, the effective implementation of sustainable initiatives covers the crucial role of having a positive effect on consumers. Thus, in exploring sustainable practices that wine companies should consider when undertaking actions that are environmentally sustainable, managers can make use of an instrument that assists them in the implementation of sustainability. Moreover, exploration of the environmental practices that wine companies adopt or consider it important to adopt can provide useful information to institutions. Awareness of the level of adoption of such practices can help institutions to understand to which practices to address their efforts and resources in order to encourage and help companies to be more sustainable.

Several future researches can be developed starting from the present study.

Firstly, our research focusses on companies with more than 20 employees, mainly located in the Tuscany region. However, most are still small companies, characterised by a lack of human and financial resources that can be dedicated to environmental or other sustainability issues. On the other hand, most of these small companies acknowledge that they have a significant environmental impact (Walker and Preuss, 2008). Thus, as a development of this work, the survey sample could be enlarged both in the analysed country, to confirm the evidences coming from the empirical research, and to others, allowing a cross-country comparison. 
Secondly, the paper focuses on environmental sustainability practices. In accordance with Schäufele and Hamm (2017), a follow up to this research should focus on the social and economic aspects of sustainability. Indeed, sustainability can be fostered if all of its dimensions (environmental, social and economic) are developed and benefit each other. In fact, environmental sustainability is relevant and beneficial for wine companies because it affects corporate image and reputation, and thus may help them to attain economic and social goals. Therefore, understanding the simultaneous environmental, social and economic impacts of business decisions could be crucial (Crane and Matten, 2016). Accordingly, further research should extend the focus to demonstrate the sustainable practices that can positively practices in wine industry

affect the economic and social dimensions.

\section{References}

Acuti, D. and Bellucci, M. (2019), "Resilient cities and regions: planning, initiatives, and perspectives", Encyclopedia of the UN Sustainable Development Goals. Springer Nature Switzerland AG, doi: 10.1007/978-3-319-71063-1_21-1.

Acuti, D., Grazzini, L., Mazzoli, V. and Aiello, G. (2019), "Stakeholder engagement in green place branding: a focus on user-generated content", Corporate Social Responsibility and Environmental Management, Vol. 26 No. 2, pp. 492-501, doi: 10.1002/csr.1703.

Alhaddi, H. (2015), "Triple bottom line and sustainability: a literature review", Business and Management Studies, Vol. 1 No. 2, pp. 6-10, doi: 10.11114/bms.v1i2.752.

Arcese, G., Flammini, S., Lucchetti, M. and Martucci, O. (2015), "Evidence and experience of open sustainability innovation practices in the food sector", Sustainability, Vol. 7 No. 7, pp. 8067-8090, doi: $10.3390 /$ su7078067.

Assandri, G., Ghidoni, F., Penner, F., Bottura, M., Brambilla, M., Bogliani, G. and Pedrini, P. (2017), "Importanza degli uccelli per la biodiversità nel vigneto", Supplement to "L'informatore agrario", Vol. 27, p. 19.

Badii, M. (2015), "La ricchezza del bio: pratiche e immaginari in una rete di eccellenza vitivinicola nel Chianti classico (Toscana). Im@go”, A Journal of the Social Imaginary, Vol. 5, pp. 11-38.

Barber, N. (2010), "Green” wine packaging: targeting environmental consumers", International Journal of Wine Business Research, Vol. 22 No. 4, pp. 423-444, doi: 10.1108/17511061011092447.

Barth, H., Ulvenblad, P.O. and Ulvenblad, P. (2017), "Towards a conceptual framework of sustainable business model innovation in the agri-food sector: a systematic literature review", Sustainability, Vol. 9 No. 9, p. 1620, doi: 10.3390/su9091620.

Bellincontro, A. (2017), "Postharvest ozone fumigation of Petit Verdot grapes to prevent the use of sulfites and to increase anthocyanin in wine”, Grape and Wine Research, Vol. 23 No. 2, pp. 200-206, doi: 10.1111/ajgw.12257.

Bellucci, M., Simoni, L., Acuti, D. and Manetti, G. (2019), "Stakeholder engagement and dialogic accounting: empirical evidence in sustainability reporting", Accounting, Auditing and Accountability Journal, doi: 10.1108/AAAJ-09-2017-3158.

Benedetto, G. (2013), "The environmental impact of a Sardinian wine by partial Life Cycle Assessment”, Wine Economics and Policy, Vol. 2 No. 1, pp. 33-41, doi: 10.1016/j.wep.2013.05.003.

Bernabeu, R., Brugarolas, M., Martinez-Carrasco, L. and Diaz, M. (2008), "Wine origin and organic elaboration, differentiating strategies in traditional producing countries", British Food Journal, Vol. 110 No. 2, pp. 174-188, doi: 10.1108/00070700810849899.

Blewitt, J. (2008), Understanding Sustainable Development, Earthscan, London, pp. 21-24.

Bonamente, E., Scrucca, F., Asdrubali, F., Cotana, F. and Presciutti, A. (2015), "The water footprint of the wine industry: implementation of an assessment methodology and application to a case study", Sustainability, Vol. 7 No. 9, pp. 12190-12208.

Borra, D., Del Vecchio, A., Lazzari, A.M., Massaglia, S. and Viberti, A. (2016), La percezione del concetto di sostenibilità nel settore vitivinicolo, FrancoAngeli, Milan. 
$\mathrm{BFJ}$

122,5

1640

Borsellino, V., Migliore, G., D’Acquisto, M., Di Franco, C.P., Asciuto, A. and Schimmenti, E. (2016), "Green'Wine through a responsible and efficient production: a case study of a sustainable Sicilian wine producer", Agriculture and Agricultural Science Procedia, Vol. 8, pp. 186-192, doi: 10.1016/j.aaspro.2016.02.092.

Boulton, R. (2017), "A self-sustainable winery, an advanced passive building and remote monitoring of environments in wineries", Journal of Agricultural Engineering, Vol. 48 No. 1, doi: 10.4081/jae. 2017.735.

Briamonte, L. (2013), Sostenibilità Ambientale, Sociale Ed Economica Della Filiera Vitivinicola, Proceedings of INEA, 17 January 2013, INEA, Rome.

Caldera, H.T.S., Desha, C. and Dawes, L. (2017), "Exploring the role of lean thinking in sustainable business practice: a systematic literature review”, Journal of Cleaner Production, Vol. 167, pp. 1546-1565, doi: 10.1016/j.jclepro.2017.05.126.

Chouinard, Y., Ellison, J. and Ridgeway, R. (2011), “The sustainable economy”, Harvard Business Review, Vol. 89 No. 10, pp. 52-62.

Christ, K.L. and Burritt, R.L. (2013), "Critical environmental concerns in wine production: an integrative review", Journal of Cleaner Production, Vol. 53, pp. 232-242, doi: 10.1016/j.jclepro. 2013.04.007.

Civera, C., De Colle, S. and Casalegno, C. (2019), "Stakeholder engagement through empowerment: the case of coffee farmers", Business Ethics: A European Review, Vol. 28 No. 2, pp. 156-174, doi: 10. 1111/beer.12208.

Colman, T. and Paster, P. (2007), "Red, white and 'green': the cost of carbon in the global wine trade”, Working Paper No. 9, American Association of Wine Economists, New York, pp. 1-17.

COMIECO (2013), available at: http://comieco.media.mweb.pro/allegati/energia-e-co2-nel-ciclo-direcupero-della- carta_28534.pdf.

Cooper, S.C.L., Stokes, P., Liu, Y. and Tarba, S.Y. (2017), "Sustainability and organizational behavior: a micro-foundational perspective", Journal of Organizational Behavior, Vol. 38 No. 9, pp. 1297-1301, doi: 10.1002/job.2242.

Crane, A. and Matten, D. (2016), Business Ethics: Managing Corporate Citizenship and Sustainability in the Age of Globalization, Oxford University Press, Oxford.

Dunphy, D., Griffiths, A. and Benn, S. (2003), Organizational Change for Corporate Sustainability: A Guide for Leaders and Change Agents of the Future, Psychology Press, London.

Duru, M., Therond, O., Martin, G., Martin-Clouaire, R., Magne, M.A., Justes, E. and Sarthou, J.P. (2015), "How to implement biodiversity-based agriculture to enhance ecosystem services: a review", Agronomy for Sustainable Development, Vol. 35 No. 4, pp. 1259-1281 doi 10.1007/s13593-015-0306-1.

Elkington, J. (1994), “Towards the sustainable corporation: win-win-win business strategies for sustainable development”, California Management Review, Vol. 36 No. 2, pp. 90-100, doi: 10. $2307 / 41165746$.

Ene, S.A., Teodosiu, C., Robu, B. and Volf, I. (2013), "Water footprint assessment in the wine making industry: a case study for a Romanian medium size production plant", Journal of Cleaner Production, Vol. 43, pp. 122-135.

Fiandrino, S., Busso, D. and Vrontis, D. (2019), "Sustainable responsible conduct beyond the boundaries of compliance: lessons from Italian listed food and beverage companies", British Food Journal, Vol. 121 No. 5, pp. 1035-1049, doi: 10.1108/BFJ-03-2019-0182.

Figge, F., Hahn, T., Schaltegger, S. and Wagner, M. (2002), "The sustainability balanced scorecardlinking sustainability management to business strategy", Business Strategy and the Environment, Vol. 11 No. 5, pp. 269-284, doi: 10.1002/bse.339.

De Filippis, T., Rocchi, L., Fiorillo, E. and Genesio, L. (2010), "Webgis application for precision viticulture: from research to operative practices”, WebMGS 2010, 1st International Workshop 1, pp. 1-6.

Fiore, M. (2016), "Direct selling in the wine sector: lessons from cellars in Italy's Apulia region", British Food Journal, Vol. 118 No. 8, pp. 1946-1959, doi 10.1108/BFJ-05-2016-0201. 
Forbes, S.L., Cohen, D.A., Cullen, R., Wratten, S.D. and Fountain, J. (2009), "Consumer attitudes regarding environmentally sustainable wine: an exploratory study of the New Zealand marketplace", Journal of Cleaner Production, Vol. 17 No. 13, pp. 1195-1199, doi: 10.1016/j.jclepro.2009.04.008.

Franceschelli, M.V., Santoro, G. and Candelo, E. (2018), "Business model innovation for sustainability: a food start-up case study”, British Food Journal, Vol. 120 No. 10, pp. 2483-2494, doi: 10.1108/ BFJ-01-2018-0049.

Gabzdylova, B., Raffensperger, J.F. and Castka, P. (2009), "Sustainability in the New Zealand wine industry: drivers, stakeholders and practices", Journal of Cleaner Production, Vol. 17 No. 11, pp. 992-998, doi: 10.1016/j.jclepro.2009.02.015.

Del Giudice, M., Khan, Z., De Silva, M., Scuotto, V., Caputo, F. and Carayannis, E. (2017), "The microlevel actions undertaken by owner-managers in improving the sustainability practices of cultural and creative small and medium enterprises: a United Kingdom-Italy comparison", Journal of Organizational Behavior, Vol. 38 No. 9, pp. 1396-1414, doi: 10.1002/job.2237.

Del Giudice, M., Garcia-Perez, A., Scuotto, V. and Orlando, B. (2019), "Are social enterprises technological innovative? A quantitative analysis on social entrepreneurs in emerging countries", Technological Forecasting and Social Change, Vol. 148, p. 119704, doi: 10.1016/j. techfore.2019.07.010.

González-García, S., Silva, F.J., Moreira, M.T., Pascual, R.C., Lozano, R.G., Gabarrell, X. and Feijoo, G. (2011), "Combined application of LCA and eco-design for the sustainable production of wood boxes for wine bottles storage", The International Journal of Life Cycle Assessment, Vol. 16 No. 3, pp. 224-237, doi: 10.1007/s11367-011-0261-2.

Grunert, K.G. (2011), "Sustainability in the food sector: a consumer behaviour perspective", International Journal on Food System Dynamics, Vol. 2 No. 3, pp. 207-218, doi: 10.18461/ijfsd.v2i3.232.

Hartley, A. (2008), "Lightweight Wine Bottles: strength as an issue in the manufacture of lightweight wine bottles”, Final Report: GlassRite: Wine. MSG009, (accessed 4 November 2008).

Hutchins, M.J. and Sutherland, J.W. (2008), "An exploration of measures of social sustainability and their application to supply chain decisions", Journal of Cleaner Production, Vol. 16 No. 15, pp. 1688-1698, doi: 10.1016/j.jclepro.2008.06.001.

ISMEA (2017), available at: http://efow.eu/wp-content/uploads/2017/11/ISMEA-report.pdf.

Jerram, C. (2015), "What does sustainability mean? Knowledge gleaned from applying mixed methods research to wine grape growing", Journal of Mixed Methods Research, Vol. 3, pp. 232-251, doi: $10.1177 / 1558689814534919$.

Johnsen, T.E., Miemczyk, J. and Howard, M. (2017), "A systematic literature review of sustainable purchasing and supply research: theoretical perspectives and opportunities for IMP-based research”, Industrial Marketing Management, Vol. 61, pp. 130-143, doi: 10.1016/j.indmarman. 2016.03.003.

Jradi, S., Chameeva, T.B., Delhomme, B. and Jaegler, A. (2018), "Tracking carbon footprint in French vineyards: a DEA performance assessment", Journal of Cleaner Production, Vol. 192, pp. 43-54, doi: 10.1016/j.jclepro.2018.04.216.

Karanasios, E. (2010), "Novel biomixtures based on local Mediterranean lignocellulosic materials: Evaluation”, Chemosphere, Vol. 80 No. 8, pp. 914-921, doi: 10.1016/j.chemosphere.2010.06.003.

Keijzers, G. (2002), "The transition to the sustainable enterprise", Journal of Cleaner Production, Vol. 10 No. 4, pp. 349-359, doi: 10.1016/S0959-6526(01)00051-8.

Linton, J.D., Klassen, R. and Jayaraman, V. (2007), "Sustainable supply chains: an introduction", Journal of Operations Management, Vol. 25 No. 6, pp. 1075-1082, doi: 10.1016/j.jom.2007. 01.012 .

Mann, S., Ferjani, A. and Reissig, L. (2012), “What matters to consumers of organic wine?”, British Food Journal, Vol. 114 No. 2, pp. 272-284, doi: 10.1108/00070701211202430.

Marangon, M., Vincenzi, S. and Curioni, A. (2019), "Wine fining with plant proteins”, Molecules, Vol. 24 No. 11, p. 2186. 
$\mathrm{BFJ}$

122,5

\section{2}

Marshall, J. and Toffel, M. (2005), "Framing the elusive concept of sustainability: a sustainability hierarchy", Environmental Science and Technology, Vol. 39 No. 3, doi: 10.1021/es040394k.

Mcmanus, P. (2008), "Mines, wines and thoroughbreds: towards regional sustainability in the upper hunter, Australia", Regional Studies, Vol. 42 No. 9, pp. 1275-1290, doi: 10.1080/ 00343400701827394.

Meier, M.S., Stoessel, F., Jungbluth, N., Juraske, R., Schader, C. and Stolze, M. (2015), "Environmental impacts of organic and conventional agricultural products-Are the differences captured by life cycle assessment?", Journal of Environmental Management, Vol. 149, pp. 193-208, doi: 10.1016/j. jenvman.2014.10.006.

Mencarelli, F. and De Propris, L. (2014), "Mappa dei modelli di produzione sostenibile: gli indicatori della sostenibilità del vino", in Forum per la Sostenibilità del Vino (Ed.), Primo Rapporto sulla Sostenibilità del Vino, Unione Italiana Vini, Rome, pp. 35-61.

Miglietta, P.P. and Morrone, D. (2018a), "Quality, prices and production efficiency: an exploratory study of Italian wines with appellation of origin", New medit: Mediterranean journal of economics, agriculture and environment = Revue méditerranéenne d'economie, agriculture et environment, Vol. 17 No. 1, pp. 73-89.

Miglietta, P.P. and Morrone, D. (2018b), "Managing water sustainability: virtual water flows and economic water productivity assessment of the wine trade between Italy and the Balkans", Sustainability, Vol. 10 No. 2, pp. 543, doi: 10.3390/su10020543.

Miglietta, P.P., Leo, F.D. and Massari, S. (2015), "Water footprint assessment of some Italian wines: a territorial perspective", International Journal of Environmental Policy and Decision Making, Vol. 1 No. 4, pp. 320-331.

Miglietta, P.P., Morrone, D. and Lamastra, L. (2018), "Water footprint and economic water productivity of Italian wines with appellation of origin: managing sustainability through an integrated approach", Science of The Total Environment, Vol. 633, pp. 1280-1286, doi: 10.1016/j.scitotenv. 2018.03.270.

Mozell, M.R. and Thach, L. (2014), "The impact of climate change on the global wine industry: challenges and solutions", Wine Economics and Policy, Vol. 3 No. 2, pp. 81-89, doi: 10.1016/j.wep. 2014.08.001.

Mueller Loose, S. and Remaud, H. (2013), "Impact of corporate social responsibility claims on consumer food choice: a cross-cultural comparison”, British Food Journal, Vol. 115 No. 1, pp. 142-166, doi: 10.1108/00070701311289920.

Navarro, A., Puig, R., Kılıç, E., Penavayre, S. and Fullana-i-Palmer, P. (2017), "Eco-innovation and benchmarking of carbon footprint data for vineyards and wineries in Spain and France", Journal of Cleaner Production, Vol. 142, pp. 1661-1671, doi: 10.1016/j.jclepro.2016.11.124.

Niccolucci, V., Galli, A., Kitzes, J., Pulselli, R.M., Borsa, S. and Marchettini, N. (2008), "Ecological footprint analysis applied to the production of two Italian wines", Agriculture, Ecosystems and Environment, Vol. 128 No. 3, pp. 162-166, doi: 10.1016/j.agee.2008.05.015.

OECD (2002), "Adoption of technologies for sustainable farming systems", Wageningen Workshop Proceedings, available at: http://www.oecd.org/greengrowth/sustainable-agriculture/2739771. pdf (accessed 25 January 2015).

Ohmart, C.P. (2004), “What does sustainability really mean?”, Wines Vines, Vol. 85 No. 11, p. 3.

OIV (2008), Risoluzione CST 1/2008 - Guida per una viticoltura sostenibile: produzione, trasformazione e condizionamento dei prodotti, available at: http://www.oiv.int/public/medias/2091/cst-1-2008-it. pdf (accessed 08 January 2018).

Point, E., Tyedmers, P. and Naugler, C. (2012), "Life cycle environmental impacts of wine production and consumption in Nova Scotia, Canada", Journal of Cleaner Production, Vol. 27, pp. 11-20, doi: 10.1016/j.jclepro.2011.12.035.

Pretorius, I.S. (2000), "Tailoring wine yeast for the new millennium: novel approaches to the ancient art of winemaking", Yeast, Vol. 16 No. 8, pp. 675-729. 
Pretorius, I.S., Van der Westhuizen, T.J. and Augustyn, O.P.H. (1999), "Yeast biodiversity in vineyards and wineries and its importance to the South African wine industry. A review", South African Journal of Enology and Viticulture, Vol. 20 No. 2, pp. 61-70, doi: 10.21548/20-2-2234.

Profitt, T. and Bramley, R. (2006), Precision Viticulture, Winetitles, Cornell University, New York, NY, p. 92.

Pullman, M.E., Maloni, M.J. and Dillard, J. (2010), "Sustainability practices in food supply chains: how is wine different?", Journal of Wine Research, Vol. 21 No. 1, pp. 35-56.

Raimondi, S. (2014), Vino e Ambiente: sostenibilità e qualità primaria nel sottobacino Iudeo-Bucari (TP), Compostampa Edizioni, Palermo.

Romero, P., Botía, P. and Navarro, J.M. (2018), "Selecting rootstocks to improve vine performance and vineyard sustainability in deficit irrigated Monastrell grapevines under semiarid conditions", Agricultural Water Management, Vol. 209, pp. 73-93, doi: 10.1016/j.agwat.2018.07.012.

Rueda, X., Garrett, R.D. and Lambin, E.F. (2017), "Corporate investments in supply chain sustainability: selecting instruments in the agri-food industry", Journal of Cleaner Production, Vol. 142, pp. 2480-2492, doi: 10.1016/j.jclepro.2016.11.026.

SAI (2015), TB 15 - Technical brief on drip irrigation and water scarcity, sustainable agriculture initiative platform, available at: http://www.saiplatform.org/uploads/Modules/Library/saitechnical- brief15-drip-irrigation-and-water-scarcity-2.pdf.

Santini, C., Cavicchi, A. and Casini, L. (2013), "Sustainability in the wine industry: key questions and research trends", Agricultural and Food Economics, Vol. 1 No. 1, p. 9, doi: 10.1186/2193-7532-1-9.

Schäufele, I. and Hamm, U. (2017), “Consumers' perceptions, preferences and willingness-to-pay for wine with sustainability characteristics: a review", Journal of Cleaner Production, Vol. 147, pp. 379-394, doi: 10.1016/j.jclepro.2017.01.118.

Schwartz, M.S. and Carroll, A.B. (2003), "Corporate social responsibility: a three-domain approach", Business Ethics Quarterly, Vol. 13 No. 4, pp. 503-530, doi: 10.5840/beq200313435.

Schwartz, M.S. and Carroll, A.B. (2008), "Integrating and unifying competing and complementary frameworks: the search for a common core in the business and society field", Business and Society, Vol. 47 No. 2, pp. 148-186, doi: 10.1177/0007650306297942.

Serio, F., Miglietta, P.P., Lamastra, L., Ficocelli, S., Intini, F., De Leo, F. and De Donno, A. (2018), "Groundwater nitrate contamination and agricultural land use: a grey water footprint perspective in Southern Apulia Region (Italy)", Science of the Total Environment, Vol. 645, pp. 1425-1431, doi: 10.1016/j.scitotenv.2018.07.241.

Silvestri, M. (2015), "Sviluppo sostenibile: un problema di definizione”, Gentes, Vol. 2 No. 2, pp. 1-5.

Stasi, A., Muscio, A., Nardone, G. and Seccia, A. (2016), "New technologies and sustainability in the Italian wine industry", Agriculture and Agricultural Science Procedia, Vol. 8, pp. 290-297.

Szolnoki, G. (2013), "A cross-national comparison of sustainability in the wine industry”, Journal of Cleaner Production, Vol. 53, pp. 243-251, doi: 10.1016/j.jclepro.2013.03.045.

Taylor, B. (2006), "Encouraging industry to assess and implement cleaner production measures", Journal of Cleaner Production, Vol. 14 Nos 6-7, pp. 601-609, doi: 10.1016/j.jclepro.2005.07.013.

Thomas, A. and Pickering, G. (2003), "The importance of wine label information”, International Journal of Wine Marketing, Vol. 15 No. 2, pp. 58-74, doi: 10.1108/eb008757.

Thompson, K. (2010), "Wine packaging alternatives: not all good wine comes in glass bottles", Virginia Tech Food and Science Technology, Vol. 1, p. 4.

Varsei, M. and Polyakovskiy, S. (2017), "Sustainable supply chain network design: a case of the wine industry in Australia”, Omega, Vol. 66, pp. 236-247, doi: 10.1016/j.omega.2015.11.009.

Villanueva-Rey, P., Vázquez-Rowe, I., Moreira, M.T. and Feijoo, G. (2014), "Comparative life cycle assessment in the wine sector: biodynamic vs. conventional viticulture activities in NW Spain”, Journal of Cleaner Production, Vol. 65, pp. 330-341, doi: 10.1016/j.jclepro.2013. 08.026 .
Environmental practices in wine industry 
$\mathrm{BFJ}$ 122,5

Voorberg, W.H., Bekkers, V.J. and Tummers, L.G. (2015), "A systematic review of co-creation and coproduction: embarking on the social innovation journey", Public Management Review, Vol. 17 No. 9, pp. 1333-1357, doi: 10.1080/14719037.2014.930505.

Vrontis, D., Bresciani, S. and Giacosa, E. (2016), "Tradition and innovation in Italian wine family businesses”, British Food Journal, Vol. 118 No. 8, pp. 1883-1897, doi: 10.1108/BFJ-05-2016-0192.

Walker, H. and Preuss, L. (2008), "Fostering sustainability through sourcing from small businesses: public sector perspectives", Journal of Cleaner Production, Vol. 16 No. 15, pp. 1600-1609, doi: 10. 1016/j.jclepro.2008.04.014.

Wiedmann, K.P., Hennigs, N., Henrik Behrens, S. and Klarmann, C. (2014). Tasting green: an experimental design for investigating consumer perception of organic wine, British Food Journal, Vol. 116 No. 2, pp. 197-211, doi: 10.1108/BFJ-04-2012-0090.

Wilson, M. (2003), “Corporate Sustainability: what is it and where does it come from?”, Ivey Business Journal, pp. 1-5.

Wojtkowski, P. (2006), Introduction to Agroecology: Principles and Practices, Food Product Press, New York, NY.

Yang, S., Song, Y. and Tong, S. (2017), "Sustainable retailing in the fashion industry: a systematic literature review”, Sustainability, Vol. 9 No. 7, p. 1266, doi: 10.3390/su9071266.

Yuan, B. and Xiang, Q. (2018), "Environmental regulation, industrial innovation and green development of Chinese manufacturing: based on an extended CDM model", Journal of Cleaner Production, Vol. 176, pp. 895-908, doi: 10.1016/j.jclepro.2017.12.034.

Zamagni, A. (2012), "Life cycle sustainability assessment", International Journal of Life Cycle Assessment, Vol. 17, pp. 373-376, doi: 10.1007/s11367-012-0389-8.

Zambonelli, C. (2004), "Lieviti indigeni e fermentazioni scalari”, Vignevini, Vol. 11, pp. 107-109.

Zanoli, R. (2007), "Quale futuro per l'agricoltura sostenibile?", Rivista di Economia Agraria, Vol. 62 No. 3, pp. 371-382.

\section{Further reading}

Annunziata, E., Pucci, T., Frey, M. and Zanni, L. (2018), "The role of organizational capabilities in attaining corporate sustainability practices and economic performance: evidence from Italian wine industry", Journal of Cleaner Production, Vol. 171, pp. 1300-1311, doi: 10.1016/j.jclepro.2017.10.035.

Arnold, M. (2017), "Fostering sustainability by linking co-creation and relationship management concepts", Journal of Cleaner Production, Vol. 140, pp. 179-188, doi: 10.1016/j.jclepro.2015.03.059.

Atkin, T., Gilinsky, A. Jr and Newton, S.K. (2012), "Environmental strategy: does it lead to competitive advantage in the US wine industry?", International Journal of Wine Business Research, Vol. 24 No. 2, pp. 115-133, doi: 10.1108/17511061211238911.

Bandinelli, R., Fani, V. and Rinaldi, R. (2017), "Customer acceptance of NFC technology: an exploratory study in the wine industry", International Journal of RF Technologies: Research and Applications, Vol. 8 Nos 1-2, pp. 1-16, doi: 10.3233/RFT-171520.

Bonn, I. and Fisher, J. (2011), "Sustainability: the missing ingredient in strategy", Journal of Business Strategy, Vol. 32 No. 1, pp. 5-14, doi: 10.1108/02756661111100274.

Carson, R. (1962), Silent Spring, Houghton Mifflin, Cambridge, MA.

Corbo, C., Lamastra, L. and Capri, E. (2014), "From environmental to sustainability programs: a review of sustainability initiatives in the Italian wine sector", Sustainability, Vol. 6 No. 4, pp. 2133-2159, doi: 10.3390/su6042133.

Cuppen, E. (2012), "A quasi-experimental evaluation of learning in a stakeholder dialogue on bioenergy", Research Policy, Vol. 41 No. 3, pp. 624-637, doi: 10.1016/j.respol.2011.12.006.

Ferri, L.M., Pedrini, M. and Pilato, V. (2016), "The management of stakeholder dialogue in different institutional contexts: an empirical study on FTSE4GOOD companies”, Journal of Cleaner Production, Vol. 136, pp. 226-236, doi: 10.1016/j.jclepro.2016.01.100. 
Giacomarra, M., Galati, A., Crescimanno, M. and Tinervia, S. (2016), "The integration of quality and safety concerns in the wine industry: the role of third-party voluntary certifications", Journal of Cleaner Production, Vol. 112, pp. 267-274, doi: 10.1016/j.jclepro.2015.09.026.

Illia, L., Romenti, S., Rodríguez-Cánovas, B., Murtarelli, G. and Carroll, C.E. (2017), "Exploring corporations' dialogue about CSR in the digital era", Journal of Business Ethics, Vol. 146 No. 1, pp. 39-58, doi: 10.1007/s10551-015-2924-6.

I numeri del vino (2017), available at: http://www.ilsole24ore.com/art/notizie/2017-07- 04/enoturismoluoghi-vino-si-continua-innovare-124057.shtml?uuid = AEXpPynB.

Linnabery, E., Cottone, D. and West, K. (2013), "Making corporate social responsibility work: recommendations for utilizing the power of a shared purpose", Industrial and Organisational Psychology, Vol. 6 No. 4, pp. 377-379, doi: 10.1111/iops.12071.

Meadows, D.H., Meadows, D.H., Randers, J. and Behrens, W.W. III (1972), The Limits to Growth: A Report to the Club of Rome (1972), Universe Books, New York, NY.

Rasul, G. and Thapa, G.B. (2004), "Sustainability of ecological and conventional agricultural systems in Bangladesh: an assessment based on environmental, economic and social perspectives", Agricultural Systems, Vol. 79 No. 3, pp. 327-351, doi: 10.1016/S0308-521X(03)00090-8.

Scuotto, V., Alexeis, G.P., Valentina, C. and Elisa, G. (2019), "Do stakeholder capabilities promote sustainable business innovation in small and medium-sized enterprises? Evidence from Italy", Journal of Business Research, in press.

Statista (2018), available at: https://www.statista.com/outlook/10030000/109/wine/united-states.

Tenuta, P. (2009), Indici e modelli di sostenibilità, Franco Angeli, Milano.

United Nations General Assembly (1987), Report of the World Commission on Environment and Development: Our Common Future, United Nations General Assembly, Development and International Co-operation: Environment, Oslo, Norway.

Vasileiou, K. and Morris, J. (2006), "The sustainability of the supply chain for fresh potatoes in Britain”, Supply Chain Management: An International Journal, Vol. 11 No. 4, pp. 317-327, doi: 10. 1108/13598540610671761.

Wang, C., Wang, Y., Geng, Y., Wang, R. and Zhang, J. (2016), "Measuring regional sustainability with an integrated social-economic-natural approach: a case study of the Yellow River Delta region of China", Journal of Cleaner Production, Vol. 114, pp. 189-198, doi: 10.1016/j.jclepro.2015.05.121.

\section{Appendix}

\begin{tabular}{lll}
\hline $\begin{array}{l}\text { Wine supply } \\
\text { chain phase }\end{array}$ & Environmental practices & Description \\
\hline Viticulture & Bio-bed systems & $\begin{array}{l}\text { Prevention of residues' dispersion in the } \\
\text { environment through an organic mix } \\
\text { Machines with a high level of automation, enabling } \\
\text { reduction of energy consumption and optimisation } \\
\text { of specific phases of the winemaking process } \\
\text { Reuse of the stones that are extracted from the } \\
\text { ground during breakdown for the planting of } \\
\text { vineyards and development of grassing in order to } \\
\text { counteract possible landslides } \\
\text { Land protection } \\
\text { Micro-irrigation } \\
\text { means of synthetic polymer pipes with low pressure } \\
\text { and placed near the plant at its roots, capable of } \\
\text { releasing drip irrigation }\end{array}$
\end{tabular}

(continued)
Environmental practices in wine industry 
Wine supply

chain phase

Environmental practices

Description

Precision viticulture

New management technologies and control of the vineyard, collecting data on crop performance, with the aim of optimising inputs

Preservation of biodiversity

Production of compost from pruning residues

Rationalisation of phytosanitary treatments

Vinification and Avoidance of chemical substances winery

Bio-building techniques

Cellar waste recovery systems Clean energy adoption

Construction of underground structures

\section{Rainwater filtering}

Bottling and distribution
Bottle made from recycled materials or alternative raw materials

Digital communication

Label made from recycled materials

Packaging made from recycled materials

Transport zero km
Creation of a suitable environment to guarantee root activity, balanced and healthy development of the vines and high quality of the grapes Derived from organic residues, which will thus form natural nutrients

Dosage of fertilising and agrochemical treatments to reduce the quantities used thanks to targeted and optimal distribution

Reducing sulphite treatments to the minimum required in order to avoid negative effects on consumers' health; treating grapes with ozone or using indigenous yeasts in fermentation Use of specific materials and construction techniques that maintain a constant temperature inside the cellars during the year

Use of waste as biomass for energy generation Use of clean energy and energy-saving systems such as solar collection system, biomass combustion or cooling geothermal plant Hypogeal or partially buried structures, with specific orientation related to natural illumination by the sun and the incidence of wind Collection of rainwater from the roofs of buildings and filtered to remove visible substances Use of bottles made from recycled materials or replacing glass with alternative containers in PET, Tetra Pak or bag-in-box

Use of digital and virtual communication without the use of paper

Use of labels made from recycled materials

Use of packaging made from recycled materials

Development of processes within the company and distribution of the finished product to the final consumer in a nearby market

Table AI.

\section{Corresponding author}

Romeo Bandinelli can be contacted at: romeo.bandinelli@unifi.it

For instructions on how to order reprints of this article, please visit our website:

www.emeraldgrouppublishing.com/licensing/reprints.htm

Or contact us for further details: permissions@emeraldinsight.com 